\title{
Pain Level in Critical Patients With Sleep Hygiene Care In Intensive Care Unit
}

\author{
Heru Suwardianto, Dyah Ayu Kartika Wulan Sari \\ STIKES RS Baptis Kediri, East Java, Indonesia \\ Corresponding author: herusuwardianto@gmail.com
}

\begin{abstract}
Bacground: Complaints in critical patients are an unpleasant experience as long as patients are admitted to the ICU. Critical patients with pain are still common and need collaboration to reduce patients in the ICU.
\end{abstract}

Purpose: This study aimed to determine the Pain Level Description of Critical Patients with Sleep Hygiene Care in the Intensive Care Unit.

Method: Research design is descriptive-analytic. The study population was all critical patients in the ICU. The study sample was a portion of critical patients who received 170 sleep hygiene care patients. The sampling technique is purposive sampling. The research variable is a description of the patient's pain level. The research instrument used a questionnaire. Data were collected and analyzed using the frequency distribution method.

Result: The results of the pain indicator on the Facial Expression study found that the majority of respondents showed grimacings $(46.6 \%)$, Body movements study found that most showed restlessness (39.4\%), Vocalization found that almost all respondents showed Tolerating ventilator or movement / Talking in normal tone / no sound (72.9\%), Muscle tension assessment found that most respondents showed Relaxed as much (51.8\%). The results of the study showed that the pain scale based on CPOT of the majority of respondents had mild pain as many as 64 respondents $(37.6 \%)$.

Conclusion: Pain description in critical patients with sleep hygiene care shows that there are still many patients who feel pain and need identification and further intervention to reduce it.

Keywords: Sleep hygiene, Pain, Critical Patients

Received July, 27, 2019; Revised August 24, 2019; Accepted September 19, 2019

How to Cite: Suwardianto, H., \& Sari, D.A.K.W, M. (2019). Pain Level in Critical Patients With Sleep Hygiene Care In Intensive Care Unit. Journal Of Nursing Practice, 3(1), 14-21.

https://doi.org/10.30994/jnp.v3i1.61 


\section{BACKGROUND}

Pain in critical patients is a real and disturbing problem in critical patients. Some conditions in critical patients are a decrease in the level of consciousness, limited body movement, and cannot express what is felt including the pain experienced. The pain is caused by the study of pain in critical patients with a decrease in an awareness that is a challenge for nurses(Gelinas, 2016). Patients in the intensive care unit have a variety of complex experiences and poor prognosis and have problems with pain and discomfort. Data shows that the incidence of pain in critically ill patients is greater than $50 \%$, the experience of pain is felt during rest and during routine clinical procedures (Barr et al., 2013; Puntillo, 2014). Some of the causes of pain are identified as traumatic injury, standard procedure (tube removal, early mobilization, endotracheal suction, and other invasive actions), acute disease, surgery, invasive equipment (Abelha, Santos, Maia, Castro, \& Barros, 2007; Barr et al., 2013). Environmental factors can also affect the pain response in patients, especially with the assessment of inappropriate pain can cause pain unknown problems so that pain is not handled (Rimawati, Suwardianto, \& VW, 2018; H. Suwardianto, 2016). Pain in critical patients who have not received optimal nursing care can have an impact on physiological functions, cognitive, mental and physical disorders, increase hospitalization time in the ICU, increase the time of ventilator use. Critical patients with untreated pain can also cause an increase in intracranial pressure (Al Sutari, Abdalrahim, Hamdan-Mansour, \& Ayasrah, 2014; Ayasrah, 2014). If we do not recognize the causes of pain in critical patients then also have the consequences of causing posttraumatic stress disorder (Jackson, Pandharipande, Girard, Brummed, \& Thompson, 2014; Nathan E, Brummel, James C. Jackson, 2013). The role of nurses in the proper management of pain depends on the assessment of pain in systematic and accurate assessment of the occurrence of pain (H. Suwardianto, Prasetyo, \& Utami, 2018; H. Suwardianto \& Selvia, 2015). Pain in critical patients should be studied routinely and structurally, seeing that each of the factors causing pain is the ICU environment, but this is often not done. Critical patients in the ICU because of the condition of the disease, causing patients to not be able to express pain subjectively, therefore nurses sometimes do not see the pain response expressed by patients because of the condition.

The results of the data show that critical patients have a severe anxiety level of $41.7 \%$, moderate anxiety level $29.2 \%$, mild anxiety $18.8 \%$, and no anxiety at $10.4 \%$ (Iskandar, 2016). VAP (Ventilator-Associated Pneumonia) is a nosocomial infectious disease that still causes deaths of around $24-50 \%$ and reaches $76 \%$ if experiencing complications (Heni, 2014). More than 63\% of critical patients complain of pain and get sedation when complaining of pain and anxiety.

The role of nurses to detect and assess environmental factors, in this case, is when patients sleep which is often called sleep hygiene. Critical patients need to identify current conditions, images that occur in critical patients when patients are admitted to the ICU. The role of nurses is very important in the assessment of critical patients and this is a challenge for ICU nurses because the severity of the patient's pain intensity is often underestimated (Georgiou, 2015; heru Suwardianto, 2018). Critical patients in expressing their pain responses who cannot communicate effectively need another technique (Hoppkins, RR, L, Spuhler, \& G.E, 2012). In the critical nursing area, many patients with sedation and intubation were unable to communicate to show their level of pain, either verbally or by showing their level of pain using pain scale tools, this made the pain 
assessment difficult in this group of patients (H. Suwardianto, 2014). This is what makes the assessment of pain in the critical nursing area very complex. Nurses in the assessment of pain in critical nursing areas require comprehensive pain assessment as an objective evaluation through observation of pain indicators. The use of a pain scale based on behavioral indicators is recommended for patients who cannot communicate their pain, by observing their motor function. The nurse in understanding and identifying critical patients to understand the condition of the next critical patient is very important and supports patient recovery.

\section{OBJECTIVE}

This study aimed to determine the Pain Level Description of Critical Patients with Sleep Hygiene Care in the Intensive Care Unit.

\section{METHODS}

The design of this study is descriptive-analytic. The population of this study was all critical patients who entered the ICU. The sample of this study amounted to 170 critical patients. The independent variables of this study were the diagnosis, age, sex, education, occupation. The dependent variable of this study is the critical patient pain scale. The research instrument used a questionnaire. Data is collected, tabulated, and coding then statistical tests are performed using frequency distribution. The study was conducted after receiving a letter ethical clearance with letter number 024/01 / V / EC / KEPK / STIKES RSBK / 2019 and had obtained a research permit from the research site.

The participants were assured that their engagement was voluntary, and that anonymity, privacy, and confidentiality of the data were guaranteed. Furthermore, they were informed about the purpose and the method of the study before signing a written informed consent. The questionnaires were distributed to eligible participants at the Baptis Hospital, and respondents were asked to complete and return them in the same time.

\section{RESULTS}

Table 1. Characteristics of Critical Patients in ICU $(\mathrm{n}=170)$

\begin{tabular}{clccc}
\hline No. & \multicolumn{1}{c}{ Characteristics } & $\sum$ & $\%$ & Mean \pm SD \\
\hline A & Diagnosis & 30 & 17,6 & $4,9 \pm 2,8$ \\
1 & CHF & 3 & 1,8 & \\
2 & Hypovolemic Shock & 15 & 8,8 & \\
3 & Miokard Infark & 47 & 27,6 & \\
4 & Respiratory Failure & 17 & 10,0 & \\
5 & Cardiogenic Shock & 11 & 6,5 & \\
6 & DCFC & 6 & 3,5 & \\
7 & Septic Shock & 14 & 8,2 & \\
8 & CKD & 17 & 10,0 & \\
9 & Dengue Shock Syndrome & 6 & 3,5 & \\
10 & Head injury & 2 & 1,2 & \\
11 & Tubercolosis & 1 & 0,6 & \\
12 & Hyponatremi & 1 & 0,6 & \\
13 & HHF & & & \\
\hline
\end{tabular}




\begin{tabular}{|c|c|c|c|c|}
\hline No. & Characteristics & $\sum$ & $\%$ & Mean \pm SD \\
\hline $\mathbf{B}$ & Gender & & & $1,50 \pm 0,50$ \\
\hline 1 & Male & 84 & 49,4 & \\
\hline 2 & Women & 86 & 50,6 & \\
\hline $\mathbf{C}$ & Age & & & $55,24 \pm 19,94$ \\
\hline 1 & 6-11 years & 12 & 7,1 & \\
\hline 2 & $26-35$ years & 5 & 2,9 & \\
\hline 3 & $36-45$ years & 2 & 1,2 & \\
\hline 4 & $46-55$ years & 17 & 10,0 & \\
\hline 5 & $56-65$ years & 31 & 18,2 & \\
\hline 6 & $>65$ years & 51 & 30,0 & \\
\hline $\mathbf{C}$ & Education & & & $3,12 \pm 1,11$ \\
\hline 1 & No school & 18 & 10,6 & \\
\hline 2 & Elementary & 33 & 19,4 & \\
\hline 3 & Junior high school & 38 & 22,4 & \\
\hline 4 & Senior high School & 72 & 42,4 & \\
\hline 5 & College & 9 & 5,3 & \\
\hline $\mathbf{D}$ & Occupation & & & $2,68 \pm 1,57$ \\
\hline 1 & Does not work & 44 & 25,9 & \\
\hline 2 & Housewife & 53 & 31,2 & \\
\hline 3 & employee & 29 & 17,1 & \\
\hline 4 & Entrepreneur & 17 & 10,0 & \\
\hline 5 & PNS & 11 & 6,5 & \\
\hline 6 & Other & 16 & 9,4 & \\
\hline $\mathbf{E}$ & Use of Mechanical Ventilators & & & \\
\hline 1 & Use & 63 & 37,1 & $1,37 \pm 0,48$ \\
\hline 2 & Do Not Use & 107 & 62 & \\
\hline
\end{tabular}

Based on the results of the study it was found that almost half of the respondents had diagnosed respiratory failure as many as 47 respondents $(27.6 \%)$, most of the respondents were female respondents as many as 86 respondents $(50.6 \%)$, almost half of the respondents had 56-65 years old as many as 51 respondents (30\%), almost half of the respondents had a high school education of 72 respondents $(42.4 \%)$, almost half of the respondents were housewives as many as 53 respondents $(31.2 \%)$ and patients using mechanical ventilators as many as 63 patients $(37.1 \%)$

Table 2. Secondary Data of Critical Patients in ICU $(n=170)$

\begin{tabular}{clcc}
\hline No & \multicolumn{1}{c}{ Variable } & Mean & SD \\
\hline 1 & Temperature $\left({ }^{\circ} \mathrm{C}\right)$ & 38,90 & 25,17 \\
\hline 2 & Systolic Blood Pressure $(\mathrm{mmHg})$ & 119,64 & 37,10 \\
\hline 3 & Diastolic blood pressure $(\mathrm{mmHg})$ & 74,56 & 23,64 \\
\hline 4 & Pulse rate (times / minutes) & 107,58 & 73,2 \\
\hline 5 & Respiratory rate (times / min) & 26,34 & 10,91 \\
\hline 6 & Mean aterial pressure $(\mathrm{mmHg})$ & 104,56 & 47,29 \\
\hline
\end{tabular}


Based on the results of the study obtained secondary data that the mean variable with an abnormal value is temperature $\left(38.9^{\circ} \mathrm{C}\right)$, blood pressure $(119.64 / 74.56 \mathrm{mmHg})$, pulse frequency (107.58 times/minute), and breathing frequency (26.34 times/minute)

Tabel 3 Pain Indicator in Critical Patients $(n=170)$

\begin{tabular}{|c|c|c|c|c|c|}
\hline No & Indicator (CPOT indocators) & $\sum$ & $\%$ & Mean & SD \\
\hline $\mathbf{A}$ & Facial Expression & & & 1,34 & 0,68 \\
\hline 1 & Relaxed, neutral & 21 & 12,4 & & \\
\hline 2 & Tense & 70 & 41,2 & & \\
\hline 3 & Grimacing & 79 & 46,5 & & \\
\hline B & Body movements & & & 1,00 & 0,88 \\
\hline 1 & $\begin{array}{l}\text { Absence of movements or } \\
\text { normal position }\end{array}$ & 66 & 38,8 & & \\
\hline 2 & Protection & 37 & 21,8 & & \\
\hline 3 & Restlessness & 67 & 39,4 & & \\
\hline $\mathbf{C}$ & $\begin{array}{l}\text { Compliance with ventilator or } \\
\text { Vocalization }\end{array}$ & & & 0,32 & 0,57 \\
\hline 1 & $\begin{array}{l}\text { Tolerating ventilator or } \\
\text { movement /Talking in normal } \\
\text { tone/no sound }\end{array}$ & 124 & 72,9 & & \\
\hline 2 & $\begin{array}{l}\text { Coughing but tolerating } \\
\text { /Sighing, moaning }\end{array}$ & 37 & 21,8 & & \\
\hline 3 & $\begin{array}{l}\text { Fighting ventilator/ Crying out, } \\
\text { sobbing }\end{array}$ & 9 & 5,3 & & \\
\hline $\mathbf{D}$ & Muscle tension & & & 0,58 & 0,67 \\
\hline 1 & Relaxed & 88 & 51,8 & & \\
\hline 2 & Tense, rigid & 64 & 37,6 & & \\
\hline 3 & Very tense or rigid & 18 & 10,6 & & \\
\hline $\mathbf{E}$ & CPOT & & & 3,25 & 1,41 \\
\hline 1 & No pain & 88 & 51,8 & & \\
\hline 2 & Mild pain & 64 & 37,6 & & \\
\hline 3 & Moderate pain & 18 & 10,6 & & \\
\hline 4 & Severe pain & 5 & 5,9 & & \\
\hline
\end{tabular}

The results of the CPOT indicator on the Facial Expression study found that the majority of respondents showed 79 grimacings (46.6\%), Body movements study found that most showed restlessness of 67 respondents (39.4\%), Compliance with ventilator or assessment. Vocalization found that almost all respondents showed Tolerating ventilator or movement / Talking in normal tone / no sound of 124 respondents (72.9\%), Muscle tension assessment found that most respondents showed Relaxed as much as 88 respondents $(51.8 \%)$. The results of the study showed that the pain scale based on CPOT of the majority of respondents had mild pain as many as 64 respondents $(37.6 \%)$. 


\section{DISCUSSION}

Based on the results of the study it was found that almost half of the respondents had a diagnosis of respiratory failure (27.6\%). Critical patients are patients with organ failure one or more target organs (Suwardianto \& Selvia, 2015). Patients to express pain are basically subjective but in patients who fail breathing identification of the scale of pain cannot be done. This makes nurses need to use different methods in patients with respiratory failure and attached a mechanical ventilator to determine the level of pain. Critical patients who are unconscious and/or have mechanical ventilators attached, for measuring pain can use CPOT. Critical patients were mostly female (50.6\%) and almost half of respondents had 56-65 years of age (30\%). This shows that critical patients are at the age of the elderly and during menopause. This is likely because some hormones have stopped working like the estrogen hormone (Suwardianto, 2016) (Barr et al., 2013). Critical patients almost half of the respondents had high school education (42.4\%), almost half of the respondents were housewives $(31.2 \%)$, this shows that education can be an indicator of perceived pain, pain experiences in critical patients (Al Sutari et al., 2014). Some critical patients use mechanical ventilators (37.1\%). Poor prognosis and in accordance with the patient's diagnosis that at most patients have respiratory failure and need to use an airway. A mechanical ventilator is one of the causes of pain, invasive action and an environment that does not support.

Sleep hygiene is a modification of the environment when the patient sleeps at night. Environmental modification in the form of temperature, noise and lighting settings (Dakin \& Margarson, 2010; Faraklas, 2013). Based on the results of the study obtained secondary data that the mean variable with an abnormal value is temperature $\left(38.9^{\circ} \mathrm{C}\right)$, blood pressure $(119.64 / 74.56 \mathrm{mmHg})$, pulse frequency (107.58 times/minute), and breathing frequency (26.34 times/minute). This shows that the process of sleep rest is important to support the patient's hemodynamics and respond to decreased pain (Barr et al., 2013; Skrobik, 2013). Critical patients treated in the ICU need to be identified with hemodynamic conditions so that they are able to show their best condition in the repair process. Hemodynamic improvement can be done with sleep hygiene by increasing optimal resting response. Sleep hygiene improves the quality of sleep, improves regulation of organ balance, and rests organs.

Critical patients can interpret the experience of pain without expressing it. Critical patients experience pain because of the environment, actions, and response to the disease. Patient pain can be identified using CPOT. The results of the study on CPOT indicators on the Facial Expression study found that most respondents showed grimacing (46.6\%), Body movements study found that most showed restlessness (39.4\%), assessment of Compliance with ventilator or Vocalization found that almost all respondents showed Tolerating ventilator or movement / Talking in normal tone / no sound $(72.9 \%)$, muscle tension assessment found that most respondents showed Relaxed (51.8\%). The results of the study showed that the pain scale based on CPOT of the majority of respondents had mild pain as many as 64 respondents (37.6\%). Critical patients with pain need to continue to get attention from measurement methods, and appropriate nursing care. The condition of the patient can continue to change to achieve optimal conditions. The role of nurses in carrying out nursing care needs to be continuously supported in achieving nursing care to reduce optimal pain. 


\section{CONCLUSION}

Critical patients with complaints of pain in the ICU had Facial Expression. It was found that the majority of respondents showed grimacing (46.6\%), Body movements study found that most showed restlessness $(39.4 \%)$, the Compliance with ventilator or Vocalization study found that almost all Respondents showed Tolerating ventilator or movement / Talking in normal tone / no sound (72.9\%), Muscle tension assessment found that most respondents showed Relaxed (51.8\%). The results of the study showed that the pain scale based on CPOT of the majority of respondents had mild pain (37.6\%).

\section{ACKNOWLEDGMENTS}

We thank the Ministry of Science, Research, Technology and Higher Education of Indonesia (RISTEKDIKTI RI) for Research Grants 2018 and providing 2019. We thank you to Director of Kediri Baptist Hospital, Nurse Erina the Chief of ICU Baptist Hospital ICU and all research respondents.

\section{REFERENCE}

Abelha, F. J., Santos, C. C., Maia, P. C., Castro, M. A., \& Barros, H. (2007). Quality of life after stay in surgical intensive care unit. BMC Anesthesiology, 7(8), 1-12. https://doi.org/10.1186/1471-2253/7/8

Al Sutari, M. M., Abdalrahim, M. S., Hamdan-Mansour, A. M., \& Ayasrah, S. M. (2014). Pain among mechanically ventilated patients in critical care units. Journal of Research in Medical Sciences : The Official Journal of Isfahan University of Medical Sciences, 19(8), 726-732. Retrieved from http://www.ncbi.nlm.nih.gov/pmc/articles/PMC4235092/

Ayasrah, S. M. (2014). Pain Assessment and Management in Critically ill Intubated Patients in Jordan: A Prospective Study. Int J Health Sci (Qassim), 8(3), 287-298.

Barr, J., Fraser, G. L., Puntillo, K., Ely, E. W., Devlin, J. W., Kress, J. P., ... Jaeschke, R. (2013). Clinical practice guidelines for the management of pain, agitation, and delirium in adult patients in the intensive care unit. Society of Critical Care Medicine, The American College of Critical Care Medicine (ACCM), 41(1), 263-306.

Dakin, J., \& Margarson, M. (2010). Current Anaesthesia \& Critical Care Sleep-disordered breathing and anaesthesia in the morbidly obese. Current Anaesthesia \& Critical Care, 21(1), 24-30. https://doi.org/10.1016/j.cacc.2009.10.008

Faraklas, I. (2013). Impact of a Nursing-Driven Sleep Hygiene Protocol on Sleep Quality. Journal of Burn Care \& Research, 34(2), 249-254.

Gelinas, C. (2016). Pain assessment in the critically ill adult: Recent evidence and new trends. Intensive and Critical Care Nursing, 34(1), 1-11.

Georgiou, E. (2015). The Impact of Pain Assessment on Critically Ill Patients' Outcomes: A Systematic Review. BioMed Research International, 1(1), 18.

Heni. (2014). Lama Hari Rawat Pasien Ventilator Associated Pneumonia Pada Pasien Dengan Ventilator Mekanik Di Icu Rsup Dr Kariadi. Univerisitas Diponegoro, 1(1), 1.

Hoppkins, R., RR, M., L, R., Spuhler, V., \& G.E, T. (2012). Physical therapy on the wards after early physical activity and mobility in the intensive care unit. Physical Therapy, 92(12), 1518-1523.

Iskandar. (2016). Gambaran Tingkat Kecemasan Keluarga Pasien Kritis yang Terpasang 
Venltilator di Ruang ICU Rumah Sakit Umum Daerah (RSUD) Tugurejo Semarang. Universitas Deponegoro, 1(1), 1.

Jackson, J., Pandharipande, P., Girard, T., Brummed, N., \& Thompson, J. (2014). Depression, post-traumatic stress disorder, and functional disability in survivors of critical illness in the brain-icu study: a longitudinal cohort study. The Lancet Respiratory Medicine, 2(5), 369-379.

Nathan E, Brummel, James C. Jackson, T. D. G. (2013). A combined early cognititive and physical rehabilitation program for people who are critically lil: The activity and cognitive therapy in the intensive care unit (ACT-ICU) trial. Physical Therapy Critical Illness, 92(12), 1580-1592.

Puntillo. (2014). Determinants of procedularal pain intensity in the intensive care unit. Am J Respir Crit Care Med, 189(1), 39-47.

Rimawati, Suwardianto, H., \& VW, A. (2018). Resilience of Knowledge and Perception Skills on the First Aid on Employees. The 2nd Joint International Conferences, 2(2), 535.

Skrobik, Y. (2013). The pain, agitation, and delirium practice guidelines for adult critically ill patients: a post-publication perspective. Ann Intensive Care, 3(9).

Suwardianto, heru. (2018). Pelatihan Penangganan Korban Tersedak Terhadap Pemahaman Tujuan, Prosedur, Kewaspadaan, Dan Evaluasi Tindakan. Jurnal Penelitian Keperawatan, 4(2), 1.

Suwardianto, H. (2014). The effectiveness of deep breathing and slow stroke back massage to decrease the blood pressure on a patient with hypertension. Indonesian Nursing Journal of Education and Clinic (INJEC), 1(1), 1-12.

Suwardianto, H. (2016). Tardive dyskenesia, motor activity, sedation scale, and cardiac workload in baptis kediri hospital. World Society of Disaster Nursing, 4(1), 1.

Suwardianto, H., Prasetyo, A., \& Utami, R. S. (2018). Effects of Physical-Cognitive Therapy (PCT) on Criticaly ill Patients in Intensive Care Uni. Hiroshima Journal of Medical Sciences, 67(1), 63-69.

Suwardianto, H., \& Selvia, D. (2015). Buku Ajar Keperawatan Kegawatdaruratan (Perspektif, Konsep, Prinsip, dan Penatalaksanaan Kegawatdaruratan). Surabaya: PT. REVKA PETRA MEDIA. 